\title{
The Use of Student Worksheet to Improve Writing Ability of Descriptive Text
}

\author{
Sanggup Barus \\ Department of Indonesian Language and Literature \\ Universitas Negeri Medan \\ Medan, Indonesia \\ Corresponding author: sanggupbarus101154@gmail.com \\ Sahat Siagian \\ Study Program Education Technology \\ Post Graduate Universitas Negeri Medan \\ Medan, Indonesia \\ Abdul Hasan Saragih \\ Study Program Education Technology \\ Post Graduate Universitas Negeri Medan \\ Medan, Indonesia
}

\begin{abstract}
In an effort to improve the quality of human resources, it is necessary that learning to write in educational institutions can realize the optimal writing ability. However, the reality shows that the ability to write descriptive text of the students of Indonesian Language and Literature Study Program Universitas Negeri Medan is not satisfied. This study aims to know whether the use of student worksheet in learning to write descriptive text can improve the ability of the students to write descriptive text. In this research, the approach used was quantitative descriptive and the method used was experiment. The results showed, firstly, the ability of the students to write descriptive text before using worksheet is categorized sufficient with an average score for 62.5 . Secondly, the ability to write descriptive text after using worksheet was categorized good with an average score for $\mathbf{7 4 . 3 2}$. This means that there is an increase for $11.82 \%$. It can be concluded that the use of student worksheet can improve the ability of the student to write descriptive text.
\end{abstract}

Keywords - student worksheet; writing ability; descriptive text

\section{INTRODUCTION}

Writing ability is an important aspect of language ability. According to Tarigan, in modern life, it is clear that writing skill is needed. It is not exaggerative to say that writing skill is a hallmark of educated people [1]. In line with that, Pawitra tells us that there is a saying which states to know the world, then read, and to be known to the world, please write [2].

One of the types of writing ability is the ability to write descriptive text. This type of ability is very important possessed by students because in writing any academic fields which as common task in university, such as thesis, book reports, scientific articles, and so forth, this type of ability is required as well. In those writings there are also micro genres, one of which is description.
The composition of description is an article that depicts or describes a particular object or certain event in words clearly and in detail so that the reader seems to share or experience what the author has directly described [3]. The characteristics are to depict an object with clear description and by involving the senses, leading the readers to feel, and to describe the characteristics of objects such as colour, size, form, and the real situation. Based on its objectives, there are two kinds of descriptions, namely suggestive descriptions and technical descriptions or expository descriptions [4]. A suggestive description is a description that describes the author's inspiration, or to stimulate his readers. The expository description is a description that aims to provide identification or information about an object, so readers can recognize it when it meets or confronts it. It means that expository description depicts an object objectively or it can be to depict as what should be in order to make the reader may imagine the condition.

In this regard, in order to improve the quality of human resources, it is necessary that writing learning in educational institutions can achieve optimal writing skill in the students themselves. However, the reality shows that the ability to write, especially the ability to write descriptive text of the students of the Indonesian Language and Literature Study Program State Universitas Negeri Medan is still low. From the interview with the lecturers of writing learning, it is known that the mastery of how to write a student descriptive text can be considered relatively good, but the ability of students in writing in the text type is relatively low. This problem is almost the same as in senior high school. Radius states that the value of the descriptive paragraph of students is still low with score 60 for $30 \%$ [5]. Of course, this is due to the lack of efforts of lecturers in learning to write by involving the student in learning actively, especially their mental. 
There are some alternatives of the cause for low ability or learning output of the student to write. From the student side, the low ability to write can be caused by lack of interest of the student related to the activities in writing, low motivation of the student, lack of ability of the student in using language, and others. From the lecturers side, the problem can be caused by the form of arrangement of the instructional material which is less relevant, lack of using relevant instructional media, instructional strategy which is less relevant, and etc.

The author offers an attempt in learning to write descriptive text, namely the use of student worksheet. Majid states that the student worksheet is the sheet containing tasks that must be done by learners [6]. It means that using worksheet, the students will get description of the material, tasks, and exercises related to instructional material. Beside to introduce one certain activity, the use of the student worksheet can accelerate the process of learning-teaching and the principle of efficiency can be achieved in the implementation of learning. In the context of writing instruction of descriptive text, the student worksheet used can be planned containing the instructions on the task, description of an object and the space where descriptive text is written.

Initially, student worksheet is used for the media for learning. However, in this discussion, student worksheet is as a form of package for instructional material. With the worksheet, the students can learn actively. The form of learning materials with student worksheet will be more interesting and more encouraging for the students in learning as well as more challenging in the activity of writing descriptive text.

This type of learning is in accordance with constructivist view. Budiningsih states that according to constructivist view, learning is a process of knowledge formation [7]. Learning to write descriptive text with the use of student worksheet can guide students in constructing knowledge in their brain. Based on his observation of an object (its parts and its characteristics) and giving meaning to it, the student is guided to construct the knowledge he/she gets. Furthermore, the student can describe it in writing.

The problems to be answered in this paper are as follows. How is the ability of the student to write descriptive text before using the student worksheet? How is the ability of the student to write descriptive text after using the student worksheet? Does the use of student worksheet improve the ability of the students to write descriptive text? In this case, the ability of the students to write descriptive text is the ability to write expository descriptive text. In accordance with these problems, this study aims to know the ability of the students to write descriptive text before using the student worksheet, to know the ability of a student to write descriptive text after using the student worksheet, and to know whether the use of student worksheet improve the ability of the student to write descriptive text.

\section{METHOD}

This research was conducted on the students of Indonesian Language and Literature Study Program Faculty of Language and Arts Universitas Negeri Medan semester 1 teaching year 2016. The subjects of this study amounted to 22 students.

The approach used in this research was descriptive quantitative approach. The method used was experimental method. The design of research was one group pre-test and post-test design which can be seen in the table below.

This research has 2 (two) variables, namely student worksheet and the writing ability of descriptive text of the students. The operational definition is that student worksheet means a form of instructional material consisting of sheets containing the instruction, figure of an object and scope of writing place of descriptive text. The writing ability of descriptive text is as the score obtained by the student after learning or doing the exercise regarding descriptive text using student worksheet.

Data collection was conducted with testing technique, namely the test of ability to write descriptive text using student worksheet and one of the contents is about a picture of house with garden. The aspects to measure in the descriptive text of the student are content, organizational content, diction, and word writing and punctuation.

To know whether the use of student worksheet in instructional writing ability of descriptive text can improve the ability of the students, with the average score before using student worksheet (average score of pre-test) compared with average score of writing ability of descriptive text after using student worksheet (average score of post-test). Here, the technique of data analysis used was percentage technique.

The category of ability of the student in writing descriptive text used in this research was the category stated by Sudijono [8], namely very good (80-100); good (66-79); sufficient (56$65)$; low (46-55); and bad (0-45). This category is used in determining the description or percentage of the ability level of the student in writing descriptive text either before using the student worksheet or after using the student worksheet.

Table 1. Research Design

\begin{tabular}{|c|c|c|c|}
\hline Class & Pre-test & Treatment & Post-test \\
\hline Experiment & $\mathrm{O} 1$ & $\mathrm{X}$ & $\mathrm{O} 2$ \\
\hline
\end{tabular}

Remarks :

O1 : test of writing ability of descriptive text before using the student worksheet.

$\mathrm{X}$ : the treatment using the student worksheet.

$\mathrm{O} 2$ : test of writing ability of descriptive text after the treatment using the student worksheet. 
Table 2. The Grids of the Instrument of the Test of Writing Ability of Descriptive Text.

\begin{tabular}{|l|l|l|l|l|l|}
\hline $\begin{array}{l}\text { The criteria } \\
\text { to measure }\end{array}$ & $\begin{array}{c}\text { Very } \\
\text { Good }\end{array}$ & Good & $\begin{array}{c}\text { Suffi- } \\
\text { cient }\end{array}$ & Low & $\begin{array}{c}\text { Percen } \\
\text { tage }\end{array}$ \\
\hline $\begin{array}{l}\text { Content: The } \\
\text { appropriatene } \\
\text { ss of the } \\
\text { content with } \\
\text { the title and } \\
\text { the } \\
\text { completeness } \\
\text { of parts of the } \\
\text { object. }\end{array}$ & $25-21$ & $20-16$ & $15-11$ & $10-5$ & $25 \%$ \\
\hline $\begin{array}{l}\text { Content } \\
\text { organization : } \\
\text { Well } \\
\text { regulated of } \\
\text { arrangement } \\
\text { of the content } \\
\text { and unity and } \\
\text { coherent in } \\
\text { paragraph }\end{array}$ & $25-21$ & $20-16$ & $15-11$ & $10-5$ & $25 \%$ \\
\hline $\begin{array}{l}\text { Diction: The } \\
\text { accuracy and } \\
\text { relevance of } \\
\text { word choice. }\end{array}$ & $25-21$ & $20-16$ & $15-11$ & $10-5$ & $25 \%$ \\
\hline $\begin{array}{l}\text { Word writing } \\
\text { and } \\
\text { punctuation: } \\
\text { The accuracy } \\
\text { of word } \\
\text { writing and } \\
\text { usage of } \\
\text { punctuation. }\end{array}$ & $25-21$ & $20-16$ & $15-11$ & $10-5$ & $25 \%$ \\
\hline
\end{tabular}

\section{RESULTS AND DISCUSSION}

The number of scores obtained by 22 students from the pre-test (before using student worksheet) is 1375 . The average

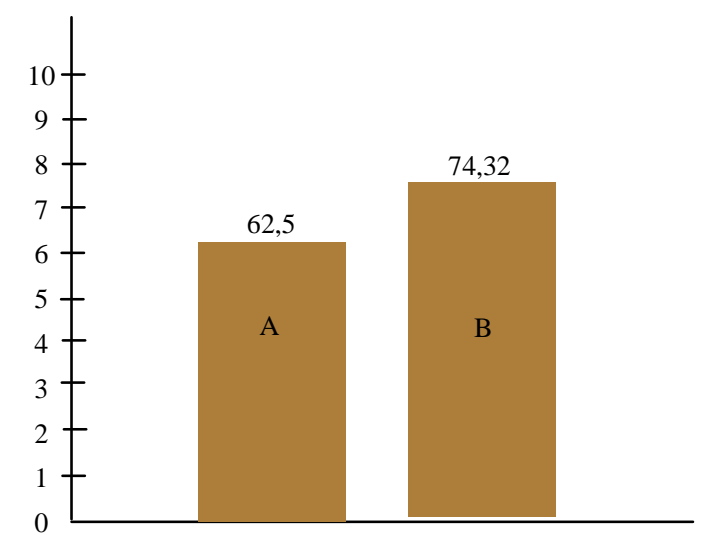

Figure of Comparison Diagram of Average Score of Writing Ability of Descriptive Text of the Students from Pre-Test and Post-Test.

Remarks :

A : average score of writing ability of descriptive text of the students from pre-test (before using student worksheet).

B : average score of writing ability of descriptive text of the students from post-test (after using student worksheet). score is 62.5 using the ability category by Sudijono, this average score is categorized sufficient. However, as the students have ever studied about how to write descriptive in the previous level, this average score of pre-test can be still categorized low.

The number of score obtained by all the students from the post-test, after following the instructional using student worksheet was 1635. The average score was 74.32. The average score of the student ability from this post-test was in the range 66-79. Thus, this average score can be categorized good.

Compared to the average score of pre-test, the average score of writing ability of descriptive text of the students have increased for $11.82 \%$. The comparison can be seen clearly in the figure above.

Further, the average score of writing ability of descriptive text of the student on every aspect of ability can be seen in the table below.

The table shows that the average score of the student on content aspect before using student worksheet is 16.3 and after using student worksheet is 21.91. It means that there is the increase for $5.61 \%$. The average score of the student on the content organization before using student worksheet is 16.1 and after using student worksheet is 20.1. It means that there is the increase for $4 \%$. The average score of the student on diction aspect before using student worksheet is 15.31 and after using student worksheet is 16.36. It means that there is the increase for $1.05 \%$. Then, the average score of the student on word writing and punctuation before using student worksheet is 14.81 and after using student worksheet is 15.95 . It means that there is the average increase for $1.14 \%$.

The increase in the average value of students is dominant on the aspect of content and on organizational aspect. It can be interpreted that it is caused by the students are helped in using student worksheet. By following the instruction and observing the pictures at the time of writing, the students can describe the objects either as a whole or parts of the object maximally with good arrangement.

The increase on average score of the student on diction aspect and word writing and punctuation is relative low. It can be interpreted that it is caused by the less influence on the use

Table 3. Score Average of the Writing Ability of Descriptive Text of the Student on Every Aspect of Ability

\begin{tabular}{|l|c|c|c|}
\hline \multicolumn{1}{|c|}{$\begin{array}{c}\text { Ability } \\
\text { Aspect }\end{array}$} & $\begin{array}{c}\text { Average Score } \\
\text { before Using } \\
\text { Student } \\
\text { Worksheet }\end{array}$ & $\begin{array}{c}\text { Average Score } \\
\text { after Using } \\
\text { Student } \\
\text { Worksheet }\end{array}$ & $\begin{array}{c}\text { Improvement } \\
(\%)\end{array}$ \\
\hline Content & 16.3 & 21.91 & 5.61 \\
\hline $\begin{array}{l}\text { Content } \\
\text { Organization }\end{array}$ & 16.1 & 20.1 & 4 \\
\hline Diction & 15.31 & 16.36 & 1.05 \\
\hline $\begin{array}{l}\text { Word Writing } \\
\text { and Punctuation }\end{array}$ & 14.81 & 15.95 & 1.14 \\
\hline
\end{tabular}


of student worksheet to the ability of the student to write descriptive text on diction and spelling aspect. Hence, in order to improve the ability of the student in selecting and using words as well as applying the rules of spelling in writing, the lecturers should think of or plan better or precise own way.

Based on that interpretation, it can be stated that to produce a good descriptive text, the author must have sufficient knowledge or experience about the object to be described. It is because the completeness of the parts or the characteristics of the object described in the descriptive text is one of the factors that determine the quality of the descriptive text.

In order to gain sufficient knowledge and experience of an object depicted in the student worksheet, it is necessary the accuracy from the student to observe it, both its parts and its composition. This is consistent with the opinion of Adelstein and Pival which state that a good description depends on sharp responses and words that are sufficient to convey the experience with concrete and specific words. Both qualitiessharp responses and adequate vocabulary are closely related to a certain extent [9].

The results of this study can be used as a material consideration in the planning of learning program to write descriptive text, especially in planning the form of instructional materials. Because, in fact it turns out that learning to write descriptive text can work well by using student worksheet.

Another reason is that the use of student worksheet can in practice realize the principles of efficiency and effectiveness in learning to write descriptive text. Without bringing students to a place to observe an object, they can learn to write descriptive text in a study room that is conducive atmosphere using student worksheet. It does not require large fees, learning to write descriptive text with the use of student worksheet is more fun and motivate students in learning.

In addition, the use of student working sheet in learning to write descriptive text can create student centered instruction. In practice, the lecturer only plays the role as facilitator and advisor. It is in accordance with as stated by Amri that instructional material with activities centered on student can be well packaged in student working sheet [10].

Besides viewed as a media in learning-teaching process, student worksheet is also viewed as one form of packaging of instructional materials. In the context of learning to write descriptive text, the student worksheet can be expressed as a form of packaging of descriptive text exercise material containing instructions, steps, work, topics, goals, themes, and clear and bright images. On the student worksheet, the space to write the descriptive text is provided for the student.
However, instructional writing of descriptive text by using student worksheet requires good preparation. The lecturer must plan student worksheet. The student worksheet must fulfill of the elements as stated in the previous. The picture of the object must show the parts as maximal as possible. To attract the attention of the student in learning, the picure of the object should be with colourful picture.

This research needs further study to know whether the use of student worksheet can also improve the ability of the student in writing in the genre of other texts. It is necessary to do in order to know to what extent the student worksheet can be used in instructional writing in general.

\section{CONCLUSION}

Based on the results and discussion in this study, the conclusion can be drawn. The writing ability of descriptive text of the student before using student worksheet is categorized sufficient. The writing ability of descriptive text of the student after using student worksheet is categorized good The use of student worksheet can improve the writing ability of descriptive text of the student. Then, it can said that beside it is considered as the media in learning-teaching process, student worksheet can be also considered as one of the package forms for instructional material.

\section{ACKNOWLEDGEMENT}

This study is conducted on the support from Chairman of Study Program Indonesian Language and Literature, Faculty of Language and Arts Universitas Negeri Medan.

\section{REFERENCES}

[1] H.G.Tarigan, Menulis Sebagai Suatu Keterampilan Berbahasa Bandung: Angkasa, 2008.

[2] M.Tyas Pawitra, Pentingnya Menciptakan Budaya Menulis di Perguruan Tinggi http://www.telkomuniversity.ac.id/article/ pentingnya menciptakan-budaya-menulis di perguruan tinggi (accessed on April 20, 2015)

[3] H.Dalman. Keterampilan Menulis. Jakarta: RajaGrafindo Persada, 2014

[4] G.Keraf. Ekposisi dan Deskripsi. Jakarta; Gramedia, 1987.

[5] T.A.Ginting, Pengaruh Penggunaan Media Gambar Fotografi terhadap Kemampuan Menulis Paragraf Deskripsi Siswa Kelas X SMA Negeri 1 Stabat Tahun Pembelajaran 2013/2014. Medan : Fakultas Bahasa dan Seni Universitas Negeri Medan, 2014.

[6] A.Majid, Perencanaan Pembelajaran Mengembangkan Standar Kompetensi Guru. Bandung : Remaja Rosdakarya, 2006.

[7] C.A.Budiningsih, Belajar dan Pembelajaran. Jakarta: Rineka Cipta, 2005.

[8] A.Sudijono, Pengantar Evaluasi Pendidikan. Jakarta : RajaGrafindo Persada, 2008.

[9] M.E. Adelstein dan J.G.Pival. The Writing Commitment. New York Harcout Brace Jovanovich, Inc, 1976.

[10] S.Amri. Pengembangan dan Model Pembelajaran dalam Kurikulum 2013. Jakarta : Prestasi Pustaka Publisher, 2013. 